DOI: https://doi.org/10.30525/978-9934-26-108-4-3

Inna Lunina

Doctor of Economic Sciences, Professor,

Corresponding Member of the

National Academy of Sciences of Ukraine

Head of Public Finance Department,

Institute for Economics and Forecasting

of the National Academy of Sciences of Ukraine

Olena Bilousova

Doctor of Economic Sciences, Leading Researcher of Public Finance Department,

Institute for Economics and Forecasting of the National Academy of Sciences of Ukraine

Nataliia Nazukova $P h D$ in Economics,

Senior Researcher of Public Finance Department Institute for Economics and Forecasting of the National Academy of Sciences of Ukraine

\title{
MODERN CHALLENGES AND NEW OPPORTUNITIES FOR FISCAL ACTIVATION OF ECONOMIC GROWTH FACTORS
}

\section{Summary}

The article dwells upon the problematic issues of present development of Ukrainian economy and social sphere through the lenses of changes caused by the pandemic. Practical approaches to state support for business entities in certain EU countries to overcome the socio-economic effects of the pandemic were summarised. The priorities of government capital investments aimed at medium-term national economic development and the instruments of fiscal support for investment and innovation activities of enterprises are determined in the article. The role of government education financing is clarified and a conclusion on the prior role of budgetary financing of preschool and primary education for the formation of future factors of economic growth is made. The necessity of balancing resources for human capital formation between the budget, business sector and households is substantiated. Specific measures of state support for families with children are proposed, which will make it possible to activate educational driver of economic growth in the pandemic circumstances. Based on the results of the study, proposals were formed on the regulatory and legal support of fiscal measures aimed at enhancing economic growth, which cover the spheres of education, science and innovation, public investment, and the formation of financial resources of the state and enterprises. 


\section{Вступ}

Для багатьох країн світу COVID-19 став найнеочікуванішим та найнебезпечнішим для економіки та суспільства викликом за останні роки. Пандемія та пов'язаний із нею тривалий локдаун негативно позначилися на фінансово-господарській діяльності підприємств призвели до зниження ділової активності, зменшення обсягів продажів, навіть згортання бізнесу (через зменшення пропозиції товарів та послуг унаслідок порушення ланцюгів поставок; скорочення внутрішнього та експортного попиту; негативного впливу факторів невизначеності на реалізацію інвестиційних планів) i, як наслідок, до втрати ліквідності та зменшення власного капіталу. Це потребувало перегляду усталених схем державної підтримки малих і середніх підприємств, допомоги великому бізнесу на тлі збільшення бюджетних видатків на охорону здоров'я (лікування хворих, придбання медичного обладнання), а також для фінансування наукових досліджень із розроблення вакцин, подальших заходів із вакцинації і реабілітації населення [1].

Зазначені проблеми актуалізують питання застосування бюджетноподаткових інструментів для подолання кризових явищ, забезпечення розвитку економіки та середньострокового економічного зростання 3 дотриманням умов стійкості державних фінансів.

Метою дослідження є обгрунтування ключових складників фіскальної активізації чинників економічного зростання в умовах пандемії.

Досягнення поставленої мети зумовило необхідність вирішення таких завдань: узагальнення міжнародного досвіду державної підтримки на різних стадіях боротьби з пандемією, розкриття впливу пандемії на національну економіку та обгрунтування ключових складників фіскальної активізації чинників економічного зростання.

\section{Розділ 1. Державна підтримка бізнесу \\ та населення в умовах пандемії}

Економічна криза, викликана COVID-19, як i будь-яка інша фінансово-економічна криза, потребує фіскальних антикризових заходів та державної підтримки посткризового розвитку економіки.

В умовах пандемії в різних країнах заходи державної допомоги суб'єктам господарювання були спрямовані переважно на збереження робочих місць та платоспроможності підприємств за допомогою різних бюджетно-податкових інструментів, зокрема: зниження ставок податку на прибуток підприємств та ПДВ, надання податкових пільг для фізичних осіб - підприємців, перенесення збитків на наступні податкові періоди, списання податкової заборгованості, відстрочення податкових платежів, надання кредитів на пільгових умовах, гарантування позик, надання цільових бюджетних трансфертів тощо [2-6].

Д. Андерсон, Е. Бергаміні, С. Брекельманс, А. Камерон, Ж. Дарвас, М.Д. Хіменес, К. Мідоес проаналізували та узагальнили численні види 
фіскальних інструментів підтримки підприємств, які застосовуються багатьма країнами світу в період пандемії COVID-19 [7]. При цьому слід звернути увагу на те, що отримані ними оцінки ефективності різних заходів щодо пом'якшення економічних наслідків пандемії COVID-19 є неоднозначними.

Г. Ліхт, Дж.О. Дорр, С. Мурманн досліджували результативність «невибіркових» видів державної допомоги, що надавалася на перших етапах уведення карантинних і обмежувальних заходів малим та середнім підприємствам без урахування їхнього докризового фінансового стану [8]. У Німеччині під час застосування таких видів державної підтримки було виявлено низку недоліків, зокрема фінансування підприємств 3 ознаками банкрутства, які утворилися до пандемії [8].

За результатами дослідження впливу кризи COVID-19 на платоспроможність підприємств Франції виявлено, що ії наслідки та подальші економічні ефекти $є$ різними для великих, середніх та малих підприємств різних видів економічної діяльності, а також різних регіонів [9].

К. Шпенгель, М. Деверо, Ю. Кригер, Н. Рідель, К. Людвіг та ін. обгрунтовують важливість адаптації різних заходів фіскальної політики (зокрема, бюджетної підтримки підприємств) до нових постпандемічних умов господарювання [10; 11$]$.

Узагальнення досвіду використання фіскальних інструментів державної допомоги суб'єктам господарювання у період пандемії свідчить про те, що їх результативність $\epsilon$ різною. Тому їх застосування у постпандемічних умовах потребує вибору найбільш дієвих та ефективних для такого періоду інструментів, а також установлення певних обмежень під час їх застосування (зокрема, щодо обсягів і термінів надання допомоги, фінансового стану отримувачів тощо).

Україна має обмежені бюджетні можливості для надання державної підтримки підприємствам та фінансування соціальної сфери порівняно 3 країнами $Є C$ [12]. Це вимагає зваженого підходу до вибору пріоритетів бюджетного фінансування заходів як щодо розвитку економічного діяльності, так і вирішення актуальних соціальних завдань, пов'язаних, зокрема, із формуванням майбутнього людського капіталу.

Економіка України зазнала відчутного впливу пандемії, яка змінила умови розвитку економіки, заклавши тенденцію до структурних змін, що активізуватимуть запровадження та розвиток IT-технологій, виявила проблеми у медичній сфері, змінила життя суспільства загалом.

Наслідками карантинних обмежень стали: призупинення діяльності багатьох суб'єктів малого та середнього бізнесу, звільнення працівників, зменшення вакансій на ринку праці. За даними Міністерства економіки, у 2020 р. показник реального ВВП зменшився на 4,2\%, у т. ч. у I кварталі на 1,3\%, у II кварталі - на 11,4\%, у III кварталі - на 3,5\%, у IV кварталі на $0,7 \%$ [13]. 
Обстеження економічної активності бізнесу, що проводилися Національним банком України у квітні 2021 р., показали, що у більшості основних видів економічної діяльності ситуація суттєво поліпшилася. Проте зберігаються песимістичні настрої підприємств щодо відновлення фінансово-господарської діяльності до докризового рівня: «індекс очікувань ділової активності у квітні 2021 р. знизився нижче рівноважного значення і становив 46,9 п. проти 51,4 п. у березні 2021 р.», у промисловості такий індекс становив відповідно 49,8 та 52,3 [14].

Індекс промислового виробництва в Україні збільшився на 2,1\% у березні 2021 р. порівняно відповідним періодом минулого року, проте зростання відбувалося значно нижчими темпами, ніж у країнах ЄС. Так, у березні 2021 р. порівняно з березнем 2020 р. індекс промислового виробництва у СС-27 зріс на 11,0\%, а у країнах Сврозоні - на 10,9\% [14].

Структурні зміни, які відбуваються під впливом вимушених змін умов господарювання, свідчать про неможливість відновлення економіки у постпандемічний період до докризового стану. Забезпечення подальшого розвитку економіки потребує змін у промисловій та бюджетно-податковій політиці, які мають ураховувати нові можливості формування ендогенних чинників економічного зростання.

Урядом України визначено механізм використання коштів фонду боротьби з гострою респіраторною хворобою COVID-19, спричиненою коронавірусом SARS-CoV-2, та ï наслідками. Фонд створено у складі державного бюджету на період дії карантину, встановленого Кабінетом Міністрів України з метою запобігання поширенню на території України зазначеної хвороби, та протягом 30 днів зі дня відміни дії карантину.

За даними Міністерства фінансів України, на боротьбу з гострою респіраторною хворобою COVID-19 у 2020 р. виділено 78,4 млрд грн, 3 яких використано 66,5 млрд грн, що становить 84\% [15]. У 2020 р. бюджетні ресурси спрямовувалися на: виплату допомоги на дітей фізичним особам - підприємцям; фінансову допомогу у випадку безробіття; надання кредитів на пільгових умовах; виплату матеріального забезпечення на поворотній основі; забезпечення готовності та реагування системи громадського здоров'я на спалахи гострої респіраторної хвороби COVID-19; забезпечення засобами індивідуального захисту працівників закладів екстреної медичної допомоги та закладів охорони здоров'я; здійснення доплат медичним та іншим працівникам; розвиток мережі та утримання автомобільних доріг загального користування державного значення тощо.

Складність вирішення проблем активізації чинників економічного зростання полягає у тому, що економіка України належить до малих відкритих сировинних економік зі спекулятивними рейтингами. Міжнародне агентство Fitch Ratings 26 лютого 2021 р. підтвердило довгостроковий рейтинг дефолту емітента в іноземній валюті (РДЕ) на рівні В зі стабільним прогнозом (слабкі показники управління, високий 
ступінь законодавчого та судового ризику для реалізації політики та низька зовнішня ліквідність щодо великих вимог 3 обслуговування державного зовнішнього боргу) [16]. Це негативно впливає на умови залучення фінансових ресурсів (державою та підприємствами) для забезпечення економічного зростання.

До важливих складників фіскальної активізації чинників економічного зростання слід віднести створення передумов для збільшення інвестицій суб'єктів господарювання. До таких передумов досить часто відносять зменшення податкового навантаження на підприємства. Однак, як свідчать результати досліджень авторів, в Україні традиційний підхід до стимулювання інвестиційної діяльності підприємств не забезпечує зростання інвестицій, оскільки головними чинниками, що заважають діяльності бізнесу, є низький рівень довіри до держави, неефективність судової системи, відсутність надійних гарантій прав власності, обмеженість інвестиційної та фінансової свободи, а також корупція, що збільшує видатки підприємницької діяльності [17].

Рівень економічної свободи в Україні у 2021 р. по головних складниках (за 100-бальною шкалою) становить 56,2, у т. ч. захист прав власності - 48,5; ефективність судової системи - 41,1; свобода інвестицій - 35,0 [18; 19].

В існуючих умовах невідкладним завданням держави щодо розвитку національної економіки $є$ забезпечення високого рівня економічної свободи за ключовими ऑii складниками. Підвищення ефективності ендогенних чинників економічного зростання потребує фіскальної підтримки інноваційно-інвестиційних процесів, зокрема за допомогою надання підприємствам інноваційної податкової пільги, що даватиме змогу зменшувати базу оподаткування податком на прибуток на проіндексовані видатки підприємств на інноваційну діяльність.

Підвищення прозорості функціонування системи державної допомоги в Україні, зокрема отримувачам, які надають послуги, що становлять загальний економічний інтерес. Відповідно до Угоди про асоціацію між Україною та Свропейським Союзом, у законодавстві України має бути закріплено порядок надання компенсацій підприємствам, уповноваженим надавати послуги, що мають загальний економічний інтерес. Такій порядок має передбачати ведення бухгалтерського обліку (зокрема, обліку витрат та доходів, пов'язаних з усіма послугами, які мають загальний економічний інтерес, та 3 кожним іншим окремим товаром або послугою, щодо яких підприємство здійснює діяльність); складання калькуляції витрат за цими видами діяльності; розкриття повної інформації щодо методів, відповідно до яких витрати та доходи призначаються або розподіляються за різними видами діяльності. 


\section{Розділ 2. Ризики та напрями активізації освітніх факторів довгострокового економічного зростання}

Вимушене зниження рівня економічної активності населення поглибило проблему доступності та якості освіти. За даними ЮНІСЕФ, $99 \%$ (з 2,36 млрд) дітей у світі опинилися в умовах обмеженого пересування, у тому числі $60 \%$ із них - унаслідок застосування різних форм локдауну [20].

Прогалини у знаннях, які виникли внаслідок закриття освітніх закладів із розгортанням пандемії COVID-19, матимуть довгострокові наслідки та негативно позначатимуться на темпах економічного зростання до 2100 p. За висновками Е. Ханушек і Л. Вессманн забезпечення постпандемічного розвитку потребує належного фінансування освітньої сфери 3 метою підвищення результативності освіти та підготовки кваліфікованих кадрів сучасного рівня [21]. Під час пандемії найбільш уразливою виявилась дошкільна освіта, оскільки зростання безробіття та зниження доходів сімей із дітьми створили перешкоди для небюджетного фінансування послуг догляду за дітьми дошкільного віку та програм раннього розвитку. Водночас слід звернути увагу на те, що фінансування освіти та раннього розвитку дітей молодшого віку належить до інвестицій із високою віддачею: суспільноекономічна віддача від дошкільної освіти більше ніж удесятеро перевищує суму вкладених у таку освіту коштів [22-24]. У цій сфері формування людського капіталу час, втрачений для раннього розвитку дітей, не може бути компенсований у майбутньому.

У країнах СС та ОЕСР досить поширене використання приватних коштів для фінансування дошкільної освіти $(0,1-0,3 \%$ ВВП), оскільки існує державна підтримка домогосподарств, які оплачують послуги освітніх установ.

В Україні, за даними Державної служби статистики [25], у 2020 р. лише 3,2\% закладів дошкільної освіти (492 ліцензовані заклади) були засновані на приватній формі власності, значна частина яких (126 заклади) знаходяться у м. Київ.

Аналіз видатків місцевих бюджетів України на дошкільну освіту за економічною та функціональною класифікацією показує, що частка капітальних видатків (видатків на придбання обладнання і предметів довготривалого вжитку, будівництво, капітальний ремонт, реконструкцію та модернізацію), від яких залежить якість матеріально-технічної бази дошкільної освіти, $є$ незначною (становить у середньому 3-4\% загальної суми видатків на дошкільну освіту, лише в окремі роки - близько 8\%). Обмеженість фінансування капітальних видатків у дошкільну освіту не дала змогу знизити завантаженість закладів у 2020 p.

Одна із сучасних можливостей вирішення цієї проблеми полягає у розширенні мережі закладів дошкільної освіти за рахунок збільшення кількості ліцензованих приватних закладів та забезпечення доступності 
приватної дошкільної освіти. Ї̈̈ практичне використання потребує спрощення процедури одержання ліцензії на надання послуг дошкільної освіти (зокрема, перегляду кількості необхідних дозвільних документів та термінів їх одержання) та розширення участі держави у фінансуванні ліцензованих приватних закладів.

В Україні (у межах реалізації програми «Гроші ходять за дитиною») до ліцензованих приватних закладів дошкільної освіти почали надходити кошти 3 місцевих бюджетів для компенсації вартості відвідування дітьми таких закладів, що дає змогу забезпечити збільшення обсягів фінансування дошкільної освіти. Щоправда, на разі єдиним успішним прикладом реалізації програми «Гроші ходять за дитиною» у сфері дошкільної освіти залишається м. Київ. Реалізація такої програми в інших регіонах потребує (за досвідом Києва [26]) прийняття рішень місцевих органів влади щодо порядку здійснення видатків на дошкільну освіту на основі базового фінансового нормативу бюджетної забезпеченості однієї дитини дошкільного віку із затвердженням відповідних формул його розрахунку.

Бюджетна підтримка приватних закладів виступить стимулом інвестування у сферу догляду за дітьми дошкільного віку, дасть змогу знизити завантаженість державних закладів, що необхідно в умовах пандемії COVID-19, стане формою державної підтримки приватного сектору, який працює у суспільно-корисній сфері та створює робочі місця, а також забезпечить контроль якості послуг у приватних закладах дошкільної освіти.

У країнах із широкою мережею незалежних від державного фінансування приватних закладів дошкільної освіти, які зазнали серйозних фінансово-економічних проблем унаслідок ужиття карантинних заходів та локдауну, першочерговими стали державні програми підтримки сфери раннього розвитку і дошкільного навчання.

Так, у Великій Британії запроваджено Схему збереження робочих місць в умовах коронавірусу (Coronavirus Job Retention Scheme) [27]. Цей вид допомоги надається відповідно до ст. 14 Закону про освіту та спрямовується на покриття витрат на заробітну плату працівників приватних закладів дошкільної освіти, які надають послуги з догляду за дітьми, розвитку та дошкільного навчання й які частково фінансуються за рахунок державних коштів. Приватний заклад дошкільної освіти може отримати допомогу по такій Схемі для виплати заробітної плати працівників.

Водночас залежні від державного фінансування дитячі садки у Великій Британії у період пандемії гарантовано фінансуються з місцевих бюджетів для забезпечення відвідування дітей віком від 2 до 4 років. Пріоритет у відвідуванні садків надано соціально незахищеним дітям та дітям робітників важливих професій. 
До викликів щодо ефективного функціонування сфери раннього розвитку дітей дошкільного віку в Україні слід віднести:

- низький рівень фінансування (у розрахунку на одного вихованця державних закладів дошкільної освіти) порівняно із сусідніми 3 Україною країнами $C C$;

- обмежене фінансування капітальних видатків на дошкільну освіту, від яких залежать можливості зменшення завантаженості відповідних закладів та якість їхньої матеріально-технічної бази;

- незначні сукупні обсяги грошових виплат сім'ям із дітьми;

- ризики зниження доходів сімей із дітьми внаслідок карантинних заходів;

- обмеженість обсягів відшкодування вартості заходів 3 енергоефективності, здійснюваних малозабезпеченими сім'ями 3 дітьми (із власних заощаджень або за рахунок кредитів банків-партнерів Урядової програми «теплих кредитів»);

- відсутність національної програми розвитку сфери раннього дитинства, яка б охоплювала питання функціонування не лише сфери догляду і навчання дітей, а й боротьбу з бідністю у ранньому віці, інформаційну підтримку сімей із дітьми тощо.

В Україні доцільно розширити підтримку приватних закладів дошкільної освіти в умовах пандемії, наприклад шляхом фінансування виплат працівникам у розмірі мінімальної заробітної плати за рахунок коштів Фонду для боротьби з COVID-19. Це дасть змогу зберегти робочі місця у приватному секторі дошкільної освіти, знизити навантаження на Фонд соціального страхування i Фонд загальнообов'язкового державного соціального страхування на випадок безробіття.

Важливим напрямом соціальної політики, спрямованої на підтримку раннього розвитку дітей, має бути державна підтримка сімей із дітьми, у тому числі за рахунок розширення певних видів грошових виплат таким сім'ям. До таких виплат доцільно віднести виплати малозабезпеченим та багатодітним сім'ям для покриття витрат на придбання дитячого одягу і взуття, комп'ютерів, засобів забезпечення Інтернету для навчання; навчальної літератури.

Функціонування сфери догляду за дітьми дошкільного віку потребує фінансування заходів, що включають не лише догляд, ранній розвиток і навчання дітей, а й харчування, створення належних умов для проживання тощо. До таких заходів має належати додаткова державна підтримка сімей із дітьми дошкільного віку для участі у програмах утеплення житлових приміщень, модернізації житла сімей із дітьми (у сільській місцевості). Незважаючи на те що в Україні діє програма теплових кредитів, державне відшкодування вартості утеплення житла в середньому становить 35-50\%. Такі кредити є недоступними для сімей із дітьми, що належать до найбільш уразливих верств населення, тому 
доцільним $\epsilon$ запровадження субсидованої програми утеплення $\mathrm{i}$ модернізації житла для таких сімей.

Збалансоване харчування дітей у закладах дошкільної освіти передбачає збільшення споживання здорових, багатих мінеральними речовинами і вітамінами продуктів (молока, овочів, фруктів), що допомагає формувати у дітей корисні харчові звички, боротися із зайвою вагою, поліпшувати загальний стан здоров'я дітей. Державні програми забезпечення дітей молочними продуктами, овочами i фруктами реалізуються у країнах ЄС. Відповідно до Рішення Комісії СС № 2020/467 від 25.03.2020 щодо розподілу допомоги Союзу державамчленам на шкільні фрукти та овочі та шкільне молоко, на період із 1 серпня 2020 р. по 31 липня 2021 р. буде виділено 145 млн євро на овочі і фрукти та 104,9 млн євро - на шкільне молоко [28].

В Україні існує програма «шкільне молоко», яку було затверджено ще в 2011 р. Проте вона фінансується з місцевих бюджетів і працює лише в окремих районах. Доцільно запровадити державні програми, спрямовані на обов'язкове введення в раціон харчування дітей дошкільного віку молока, овочів і фруктів високої якості місцевого походження. Успішна реалізація програми «Шкільне молоко» та запровадження програми «Шкільні овочі та фрукти» потребує законодавчого закріплення відповідних заходів, зокрема в законах України «Про освіту», «Про дошкільну освіту» та у Бюджетному кодексі України.

Трансформація фінансування сфери догляду за дітьми молодшого віку потребує також внесення змін до законодавства 3 питань соціального захисту в частині запровадження додаткової оплачуваної відпустки одному з батьків, які здійснюють догляд за малолітніми дітьми та учнями початкової школи, на період карантину у дитячих садках та школах.

\section{Розділ 3. Ключові складники фіскальної активізації чинників економічного зростання}

Вищезазначені заходи фіскальної політики для активізації ендогенних чинників економічного зростання мають знайти відображення у положеннях Бюджетної декларації на середньострокову перспективу. Зокрема, пріоритетні напрями бюджетної політики на 2022-2024 pp. мають грунтуватися на положеннях Програми діяльності Кабінету Міністрів України, Цілей сталого розвитку України на період до 2030 р., Стратегії економічної безпеки України на період до 2025 p., Національної економічної стратегії на період до 2030 р. тощо. Це означає, що до ключових складників фіскальної активізації чинників зростання економіки України має належати державна підтримка:

- пріоритетності розвитку науки та інновацій, ураховуючи, що витрати на дослідження i розробки є одним із головних критеріїв інноваційності національних економік; 
- розвитку освіти, зокрема дошкільної;

- розвитку української промисловості, орієнтованої на виробництво високотехнологічної продукції;

- створення в Україні повного циклу виробництва товарів, критично необхідних в умовах, що становлять загрозу життю і здоров'ю громадян;

- експортерів для розширення присутності української продукції на зовнішніх ринках, зокрема на ринку СС.

Державна політика у сфері науки має передбачати, що у середньостроковій перспективі буде продовжено здійснення заходів щодо відновлення статусу вітчизняної науки як основного інструменту технологічного та інноваційного розвитку держави. Тому до завдань уряду у середньостроковому періоді необхідно віднести положення щодо стратегічних напрямів розвитку науки та інновацій. При цьому зростання видатків на фінансування наукових проєктів, грантових та стипендіальних програм (у тому числі для молодих учених) має відбуватися одночасно зі зростанням загального обсягу видатків державного бюджету на науку. Водночас Бюджетна декларація на 2022-2024 pр. має містити конкретні показники загального обсягу видатків на реалізацію заходів державної політики у сфері науки, грантової підтримки наукових досліджень через Національний фонд досліджень та видатків державного бюджету на забезпечення діяльності Національного фонду досліджень, що знаходяться у складі видатків Міністерства освіти і науки.

Формування планів державних капітальних вкладень на розроблення та реалізацію державних інвестиційних проєктів, визначення пріоритетних сфер вкладення бюджетних коштів, до яких, окрім сфер охорони здоров'я, освіти, науки та інновацій, доцільно включити промисловість, яка орієнтована на виробництво високотехнологічної продукції, на створення в Україні повного циклу виробництва товарів, критично необхідних в умовах, що становлять загрозу життю і здоров'ю громадян; на підтримку українського експортера для розширення присутності української продукції на зовнішніх ринках, зокрема на ринку СС.

До пріоритетних завдань податкової політики слід віднести наближення норм національного податкового законодавства 3 податку на прибуток підприємств до положень європейського законодавства в частині формування бази оподаткування (законодавчого визначення видів витрат, які не повинні зменшувати базу оподаткування з податку на прибуток, а також визначення частини чистого прибутку (доходу) державних або комунальних унітарних підприємств та їх об'єднань, що вилучається до відповідного бюджету, та дивідендів (доходу), нарахованих на акції (частки, паї) господарських товариств, у статутних капіталах яких є державна або комунальна власність). 
Під час формування державної політики 3 питань оплати праці працівників бюджетної сфери, працівників державних органів та суддів доцільно передбачити положення щодо обмеження оплати праці керівників та членів наглядових рад підприємств державного сектору економіки.

Необгрунтоване збільшення заробітних плат керівників суб'єктів господарювання державного сектору економіки поглиблюватиме проблеми зменшення надходжень від податку на прибуток підприємств та частини прибутку підприємств до бюджету, збільшення бюджетних субсидій населенню (житлових), а також недостатності бюджетного фінансування науки, охорони здоров'я, освіти та економічної діяльності.

Установлення таких обмежень дасть змогу зменшити фіскальні ризики, збільшити надходження до бюджету податку на прибуток підприємств, частини чистого прибутку (доходу) та дивідендів на державну частку (частини чистого прибутку (доходу) державних унітарних підприємств та їх об'єднань, що вилучається до державного бюджету, та дивідендів (доходу), нарахованих на акції (частки) господарських товариств, у статутних капіталах яких $\epsilon$ державна власність).

\section{Висновки}

Соціально-економічні наслідки пандемії COVID-19 стали серйозним викликом для урядів та населення більшості країн світу. В умовах пандемії були застосовані різни заходи та інструменти державної підтримки суб'єктів господарювання та населення, зокрема пільгових ставок оподаткування, відстрочення податкових платежів, пільгового кредитування, надання фінансової допомоги сім'ям із дітьми.

До важливих складників політики фіскальної активізації чинників економічного зростання у сучасних умовах належать забезпечення розвитку науки та інновацій (відновлення статусу вітчизняної науки як основного інструменту технологічного та інноваційного розвитку держави), сучасної освіти, зокрема дошкільної, української промисловості з високою часткою доданої вартості.

До пріоритетних напрямів державних капітальних вкладень для розвитку національної економіки належить реалізація інвестиційних проєктів, орієнтованих на виробництво високотехнологічної промислової продукції, на створення в Україні повного циклу виробництва критично необхідних товарів, а також експортної продукції, зокрема для поставок у країни СС.

Інноваційний розвиток національної економіки потребує кадрів високої кваліфікації, а отже, забезпечення нової якості освіти. Узагальнення результатів сучасних досліджень щодо соціальноекономічної віддачі від освіти засвідчує необхідність реалізації концепції інвестування в освіту на ранніх етапах життя. 
Недофінансування дошкільної освіти може призвести до зменшення людського капіталу, тому пріоритетне бюджетне фінансування дошкільної та початкової освіти $є$ важливою передумовою активного формування майбутніх чинників економічного зростання.

До нових можливостей фіскальної активізації розвитку мережі закладів дошкільної освіти за рахунок ліцензованих приватних закладів слід віднести збільшення бюджетних видатків, зокрема у рамках програми «Гроші ходять за дитиною» у регіонах України. Забезпечення ефективності таких видатків потребує затвердження місцевими органами влади положень щодо порядку використання коштів комунальними та приватними закладами та формульного визначення базового фінансового нормативу бюджетної забезпеченості однієї дитини дошкільного віку.

Фінансування видатків, необхідних для активізації соціальноекономічних чинників довгострокового зростання національної економіки, потребує створення надійного базису формування бюджетних доходів. У контексті вирішення цього завдання необхідно привести національне податкове законодавство у відповідність до норм європейського законодавства, зокрема в частині формування бази стягнення податку на прибуток та дивідендів (доходу), нарахованих на акції (частки, паї) господарських товариств, у статутних капіталах яких $\epsilon$ державна або комунальна власність.

\section{Список використаних джерел:}

1. Геєць В.М., Луніна І.О., Степанова О.В. Бюджетні можливості України щодо фінансування вакцинації проти COVID-19 в умовах розвитку глобального ринку вакцин. Економіка України. 2021. № 6. С. 3-20.

2. Rahim F., Allen R., Barroy H., Gores L., Kutzin1 J. COVID-19 Funds in Response to the Pandemic. August 26, 2020. URL: https://blog-pfm.imf.org/pfmblog/2020/08/-covid19-funds-in-response-to-the-pandemic-.html

3. Gbohoui W., Medas P. Fiscal Rules, Escape Clauses, and Large Shocks / IMF Fiscal Affairs Department: Washington DC. 2020. URL: https://www.imf.org/en/Publications/ SPROLLs/covid19-special-notes

4. Mooij R., Fenochietto R., Hebous S., Leduc S., Osorio-Buitron C. Tax Policy for Inclusive Growth after the Pandemic. December 16, 2020. URL: https://www.imf.org

5. Benmelech E., Tzur-Ilan N. The determinants of fiscal and monetary policies during the COVID-19 crisis. Working Paper 27461. URL: http://www.nber.org/papers/w27461

6. Council Regulation (EU) 2020/521 of 14 April 2020 activating the emergency support under Regulation (EU) 2016/369, and amending its provisions taking into account the COVID-19 outbreak. ST/7169/2020/INIT

7. Anderson J., Bergamini E., Brekelmans S., Cameron A., and al. The fiscal response to the economic fallout from the coronavirus. 24 November 2020. URL: https://www.bruegel.org/publications/datasets/covid-national-dataset

8. Licht G., Dörr J., Murmann S. Staatliche Corona-Hilfen führen zu Rückstau bei Unternehmensinsolvenzen. ZEWNEWS. März 2021. URL: https://ftp.zew.de/pub/zewdocs/zn/zn0321.pdf 
9. Guerini M., Nesta L., Ragot X., Schiavo S. Firm liquidity and solvency under the Covid-19 lockdown in France. OFCE Policy brief. 76. July 6, 2020. URL: https://www.ofce.sciences-po.fr/pdf/pbrief/2020/OFCEpbrief76.pdf

10. Tax Systems in Times of COVID-19. Virtual Annual Conference of the Leibniz Science Campus Mannheim Taxation. URL: https://www.zew.de/en/zew/news/taxsystems-in-times-of-covid-19

11. Ludwig C. Tax Reliefs Primarily Help Larger Companies. ZEW. URL: https://www.zew.de/en/press/latest-press-releases/tax-reliefs-primarily-help-largercompanies

12. Стійкість державних фінансів України у довгостроковій перспективі : колективна монографія / І.О. Луніна та ін. ; за ред. д.е.н. І.О.Луніної ; НАН України, ДУ «Ін-т екон. та прогнозув. НАН України». Київ, 2020. 364 с. URL: http://ief.org.ua/docs/mg/333.pdf

13. Міністерство розвитку економіки, торгівлі та сільського господарства України. Звіт про діяльність 2020. URL: www.me.gov.ua

14. Огляд економічної активності (підсумки квітня 2021 року). Міністерство економіки України. URL: https://www.me.gov.ua

15. Інформація щодо спрямування бюджетних коштів, передбачених у державному бюджеті на 2020 рік Фонду боротьби з COVID-19 відповідно до прийнятих постанов КМУ. Міністерство фінансів Украӥни. URL: https://mof.gov.ua/ uk/data_and_analytics-433

16. Fitch Ratings. Ukraine. 2021. 26 Feb. URL: https://www.fitchratings.com/ entity/ukraine-80442268

17. Луніна I.О., Білоусова О.С., Фролова Н.Б. Конкурентоспроможність податкової системи в контексті розширення фіскального простору України. Економіка Украӥни. 2020. № 10. С. 34-53.

18. The Heritage Foundation. 2021. URL: https://www.heritage.org

19. Index of Economic Freedom. 2021. URL: https://www.heritage.org/index

20. Gromada A., Richardson D., Rees G. Childcare in a global crisis: the impact of COVID-19 on work and family life. Innocenti Research Briefs. IRB 2020-18, UNICEF Office of Research - Innocenti, Florence.

21. Hanushek E., Woessman L. The economic impacts of learning losses. Education Working Papers. 2020. No. 225, OECD Publishing, Paris.

22. Zubairi P. R. Bright and Early: How financing pre-primary education gives every child a fair start in life. University of Cambridge. 2017. URL: https://s3.amazonaws.com/ theirworld-site-resources/Reports/Theirworld-Report-Bright-and-Early-June-2017.pdf

23. Belle V. Early Childhood Education and Care and its long-term effects on educational and labour market outcomes. European Union. 2016. URL: https://www.rand.org/pubs/research_reports/RR1667.html

24. Psacharopoulos G., Patrinos H. Returns to Investment in Education: A Further Update. Education Economics. 2004. № 12(2). P. 111-134.

25. Статистична інформація «Дошкільна освіта в Україні у 2020 році». Київ : Державна служба статистики України, 2021. URL: http://www.ukrstat.gov.ua/

26. Рішення Київської міської ради «Про затвердження Порядку здійснення видатків на дошкільну освіту у місті Києві на основі базового фінансового нормативу бюджетної забезпеченості» від 13.09.2018 № 1369/5433.

27. Coronavirus (COVID-19): financial support for education, early years and children's social care. Guidance. URL: https://www.gov.uk/government/publications/ coronavirus-covid-19-financial-support-for-education-early-years-and-childrens-social-care/

28. Commission Implementing Decision (EU) 2020/467 of 25 March 2020 fixing the definitive allocation of Union aid to Member States for school fruit and vegetables and for 
school milk for the period from 1 August 2020 to 31 July 2021 and amending Implementing Decision C(2019) 2249 final (notified under document C(2020) 1795).

\section{References:}

1. Heiets V.M., Lunina I.O., Stepanova O.V. (2021) Biudzhetni mozhlyvosti Ukrainy shchodo finansuvannia vaktsynatsii proty COVID-19 v umovakh rozvytku hlobalnoho rynku vaktsyn [Budgetary possibilities of Ukraine on financing of vaccination against COVID-19 in the conditions of development of the global market of vaccines]. Ekonomika Ukrainy, no. 6, pp. 3-20. (in Ukrainian)

2. Rahim F., Allen R., Barroy H., Gores L., Kutzin1 J. (2020) COVID-19 Funds in Response to the Pandemic. Retrieved from: https://blog-pfm.imf.org/pfmblog/ 2020/08/covid-19-funds-in-response-to-the-pandemic-.html

3. Gbohoui W., Medas P. (2020) Fiscal Rules, Escape Clauses, and Large Shocks / IMF Fiscal Affairs Department: Washington DC. Retrieved from: https://www.imf.org/ en/Publications/SPROLLs/covid19-special-notes

4. Mooij R., Fenochietto R., Hebous S., Leduc S., Osorio-Buitron C. (2020) Tax Policy for Inclusive Growth after the Pandemic. Retrieved from: https://www.imf.org

5. Benmelech E., Tzur-Ilan N. (2020) The determinants of fiscal and monetary policies during the COVID-19 crisis. Working Paper 27461. Retrieved from: http://www.nber.org/ papers/w27461

6. Council Regulation (EU) 2020/521 of 14 April 2020 activating the emergency support under Regulation (EU) 2016/369, and amending its provisions taking into account the COVID-19 outbreak. ST/7169/2020/INIT. Retrieved from: http://data.europa.eu/eli/ reg/2020/521/oj

7. Anderson J., Bergamini E., Brekelmans S., Cameron A., and al. (2020) The fiscal response to the economic fallout from the coronavirus. Retrieved from: https://www.bruegel.org/publications/datasets/covid-national-dataset

8. Licht G., Dörr J., Murmann S. (2021) Staatliche Corona-Hilfen führen zu Rückstau bei Unternehmensinsolvenzen. ZEWNEWS. Retrieved from: https://ftp.zew.de/pub/zewdocs/zn/zn0321.pdf (in German).

9. Guerini M., Nesta L., Ragot X., Schiavo S. (2020) Firm liquidity and solvency under the Covid-19 lockdown in France. OFCE Policy brief. 76. Retrieved from: https://www.ofce.sciences-po.fr/pdf/pbrief/2020/OFCEpbrief76.pdf

10. Tax Systems in Times of COVID-19. Virtual Annual Conference of the Leibniz Science Campus Mannheim Taxation. Retrieved from: https://www.zew.de/en/zew/news/ tax-systems-in-times-of-covid-19

11. Ludwig C. (2020) Tax Reliefs Primarily Help Larger Companies. ZEW. Retrieved from: https://www.zew.de/en/press/latest-press-releases/tax-reliefs-primarily-help-largercompanies

12. Lunina I.O., Bilousova O.S., Tverdokhlibova D.V. ta in. (2020) Stiikist derzhavnykh finansiv Ukrainy u dovhostrokovii perspektyvi [Sustainability of public finances of Ukraine in the long run]; kolektyvna monohrafiia. In-t ekon. ta prohnozuv. NAN Ukrainy. Retrieved from: http://ief.org.ua/docs/mg/333.pdf (in Ukrainian)

13. Ministerstvo rozvytku ekonomiky, torhivli ta silskoho hospodarstva Ukrainy. Zvit pro diialnist 2020 [Ministry of Economic Development, Trade and Agriculture of Ukraine. Activity Report 2020]. Retrieved from: www.me.gov.ua (in Ukrainian)

14. Ohliad ekonomichnoi aktyvnosti (pidsumky kvitnia 2021 roku) [Review of economic activity (results of April 2021]. Ministerstvo ekonomiky Ukrainy. Retrieved from: https://www.me.gov.ua (in Ukrainian)

15. Informatsiia shchodo spriamuvannia biudzhetnykh koshtiv, peredbachenykh $u$ derzhavnomu biudzheti na 2020 rik Fondu borotby z COVID-19 vidpovidno do 
pryiniatykh postanov KMU [Information on the direction of budget funds provided in the state budget for 2020 of the Fund for Combating COVID-19 in accordance with the adopted resolutions of the Cabinet of Ministers]. Ministerstvo finansiv Ukrainy. Retrieved from: https://mof.gov.ua/uk/data_and_analytics-433

16. Fitch Ratings. Ukraine (2021. 26 Feb.). Retrieved from: https://www.fitchratings.com/entity/ukraine-80442268 (in Ukrainian)

17. Lunina I.O., Bilousova O.S., Frolova N.B. (2020) Konkurentospromozhnist podatkovoi systemy $\mathrm{v}$ konteksti rozshyrennia fiskalnoho prostoru Ukrainy [Competitiveness of the tax system in the context of expanding the fiscal space of Ukraine]. Ekonomika Ukrainy. no. 10. pp. 34-53. (in Ukrainian)

18. The Heritage Foundation (2021). Retrieved from: https://www.heritage.org/ index/explore?view=by-region-country-year

19. Index of Economic Freedom. 2021. Retrieved from: https://www.heritage.org/index/ (accessed 06 July 2021).

20. Gromada A., Richardson D., Rees G. (2020) Childcare in a global crisis: the impact of COVID-19 on work and family life. Innocenti Research Briefs. IRB 2020-18, UNICEF Office of Research - Innocenti, Florence.

21. Hanushek E., Woessman L. (2020) The economic impacts of learning losses. Education Working Papers. no. 225, OECD Publishing, Paris.

22. Zubairi P.R. (2017) Bright and Early: How financing pre-primary education gives every child a fair start in life. University of Cambridge. Retrieved from: https://s3.amazonaws.com/theirworld-site-resources/Reports/Theirworld-Report-Brightand-Early-June-2017.pdf

23. Belle V. (2016) Early Childhood Education and Care and its long-term effects on educational and labour market outcomes. European Union. Retrieved from: https://www.rand.org/pubs/research_reports/RR1667.html

24. Psacharopoulos G., Patrinos H. (2004) Returns to Investment in Education: A Further Update. Education Economics, 12(2), 111-134.

25. Statystychna informatsiia «Doshkilna osvita v Ukraini u 2020 rotsi» [Statistical information «Preschool education in Ukraine in 2020»]. Derzhavna sluzhba statystyky Ukrainy. 2021. Retrieved from: http://www.ukrstat.gov.ua/ (in Ukrainian)

26. Rishennia Kyivskoi Miskoi Rady. Pro zatverdzhennia Poriadku zdiisnennia vydatkiv na doshkilnu osvitu u misti Kyievi na osnovi bazovoho finansovoho normatyvu biudzhetnoi zabezpechenosti [On approval of the Procedure for spending on preschool education in the city of Kyiv on the basis of the basic financial standard of budget security»]. 13.09.2018 no. 1369/5433. (in Ukrainian)

27. Coronavirus (COVID-19): financial support for education, early years and children's social care. Guidance. Retrieved from: https://www.gov.uk/government/ publications/coronavirus-covid-19-financial-support-for-education-early-years-and-childrenssocial-care/ Updated 27 May 2021

28. Commission Implementing Decision (EU) 2020/467 of 25 March 2020 fixing the definitive allocation of Union aid to Member States for school fruit and vegetables and for school milk for the period from 1 August 2020 to 31 July 2021 and amending Implementing Decision C(2019) 2249 final (notified under document C(2020) 1795). Retrieved from: https://eur-lex.europa.eu/legal-content/EN/TXT/?uri=uriserv\%3AOJ.L_. 2020.098.01.0034.01.ENG\#d1e32-36-1 